\title{
Evaluasi Kapasitas Saluran Drainase UNESA dengan Adanya Pengembangan Kawasan Surabaya Barat
}

\author{
Panglima Raizal Mahendra Norman, Dr. Ir. Edijatno \\ Jurusan Teknik Sipil,Fakultas Teknik Sipil dan Perencanaan, Institut Teknologi Sepuluh Nopember (ITS) \\ Jl. Arief Rahman Hakim, Surabaya 60111 Indonesia \\ e-mail: panglimaibnunorman@gmail.com
}

\begin{abstract}
Abstrak - Surabaya Barat merupakan daerah yang paling diminati untuk pengembangan wilayah untuk perumahan dan properti. Semakin banyak perubahan alih fungsi lahan untuk keperluan properti dan perumahan, semakin besar pula limpasan air yang menuju saluran drainase. Banjir merupakan salah satu dampak negatif yang disebabkan oleh debit air hujan yang melimpas karena perubahan alih fungsi lahan yang besar pada suatu kawasan.

Saluran Sekunder UNESA merupakan saluran penyebab terjadinya banjir, karena saluran yang menjadi hilir dari ketiga lokasi yang berbeda (Pakuwon, Citraland, dan UNESA) mendapatkan debit limpasan yang besar. Dari hasil perhitungan evaluasi, debit limpasan yang masuk tidak sesuai dengan kapasitas Saluran Sekunder UNESA. Debit yang masuk dari kawasan Pakuwon sebesar $16.6 \mathrm{~m}^{3} / \mathrm{det}$, dari kawasan citraland sebesar $8.13 \mathrm{~m}^{3} / \mathrm{det}$, dan dari kawasan UNESA sebesar $8 \mathrm{~m}^{3} /$ det. Sedangkan kapasitas saluran sekunder UNESA yang terbesar sekitar $33.8 \mathrm{~m}^{3} /$ det.

Solusi yang diberikan yaitu dengan menahan debit yang masuk dari tiap kawasan. Debit yang masuk dari kawasan pakuwon ditahan hingga $7 \mathrm{~m}^{3} / \mathrm{det}$, dari citraland ditahan hingga $3.5 \mathrm{~m}^{3} / \mathrm{det}$, dan kawasan UNESA ditahan hingga 4 $\mathrm{m}^{3} /$ det. Dengan demkian masalah banjir yang terjadi dapat diselesaikan.
\end{abstract}

Kata kunci-Drainase, Banjir, Saluran Sekunder UNESA

\section{PENDAHULUAN}

S URABAYA Barat merupakan daerah yang paling diminati oleh para developer dalam pengembangan wilayah perumahan dan properti. Semakin banyak perubahan alih fungsi lahan untuk keperluan properti dan perumahan, semakin besar pula limpasan air yang menuju saluran drainase. Karena lahan yang dapat meresap air diubah menjadi lahan yang kedap air. Sehingga nilai koefisien aliran permukaan semakin besar dan debit air seluruhnya menjadi debit limpasan. Akibatnya saluran existing tidak dapat menahan debit yang masuk.

Sungai UNESA merupakan Saluran Sekunder yang terletak di kawasan Surabaya Barat. Saluran tersebut merupakan saluran alami yang menjadi hilir dari Saluran Sekunder Raya Pakuwon, Saluran Tersier Pakuwon, Saluran Tersier UNESA dan Saluran-Saluran dari Citraland. Lokasi Saluran Sekunder UNESA terletak pada Jalan
Pakuwon Indah Lontar Timur yang berada pada sistem drainase Lidah Kulon.

Banyak saluran drainase dari ketiga lokasi (Pakuwon, Citaland, dan UNESA) yang masuk ke Saluran Sekunder UNESA, mengakibatkan meningkatnya debit limpasan air. Pada musim penghujan, terjadi intensitas hujan yang tinggi maka terjadi banjir pada saluran tersebut karena kapasitas existing yang tidak sesuai dengan debit yang terjadi. Akibatnya banyak terjadi kerusakan pada saluran itu, antara lain kerusakan tebing dan kerusakan pada dasar saluran. Rusaknya dinding pagar pembatas Pakuwon juga disebabkan meningkatnya limpasan air yang masuk ke Saluran Sekunder UNESA. Sehingga aliran menjadi tertahan dan meluap ke daratan di sepanjang Saluran Sekunder Raya Pakuwon. Dari informasi data yang ada, limpasan debit yang masuk

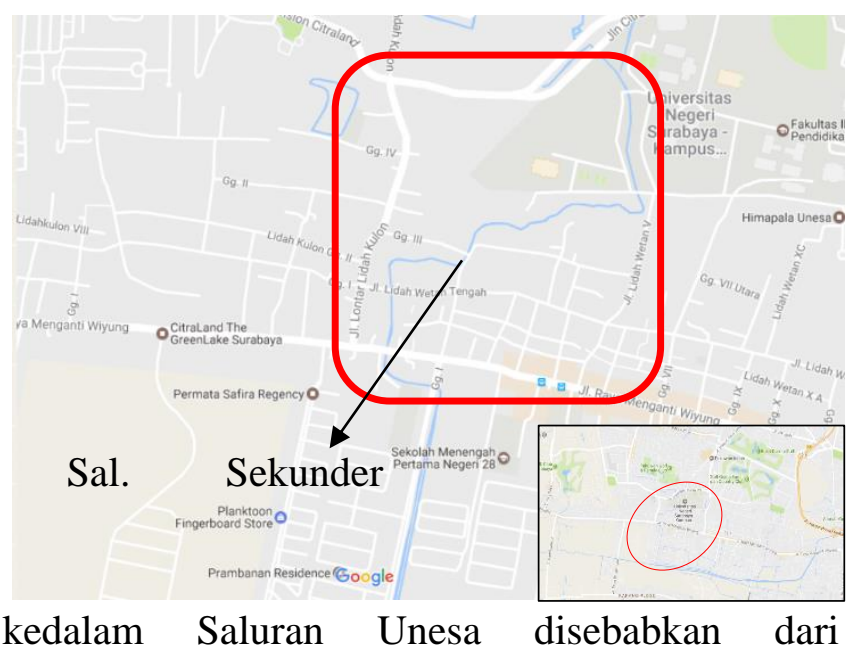
perumahan Ciputra dan Pakuwon. Dikhawatirkan pihak developer tidak memperhitungkan buangan debit yang akan masuk kedalam Saluran Unesa

Secara umum masalah banjir di Kota Surabaya hingga saat ini masih belum dapat teratasi secara menyeluruh. Sehingga limpasan air yang terjadi sebaiknya dikelola dengan baik agar tidak membebani Saluran Sekunder UNESA dan tidak menyebabkan genangan pada kawasan tersebut. 
Maka dari itu, hal ini dapat diatasi dengan penambahan fasilitas-fasilitas drainase seperti pembangunan kolam tampung; penambahan saluran pembuang lain agar tidak menumpuk pada satu saluran pembuang; penambahan pintu air untuk mengontrol air yang mengalir; penambahan pompa.

\section{METODE PENELITIAN}

Metode yang digunakan dalam perencaana ini adalah sebagai berikut :

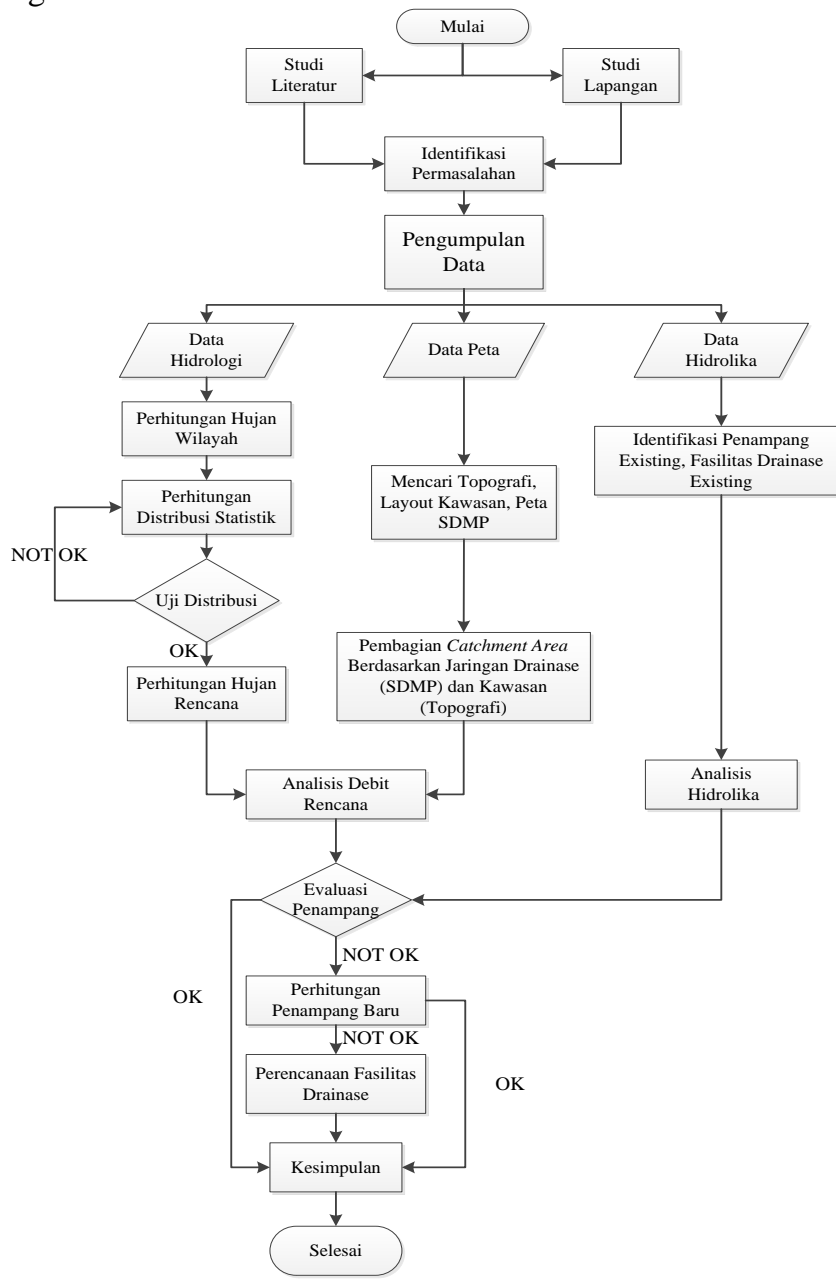

Gambar. 2. Diagram Alir Metodologi Evaluasi

\section{HASIL DAN DISKUSI}

\section{A. Analisis Hidrologi}

Analisis Hidrologi diperlukan untuk dapat mengetahui secara detail parameter-parameter hidrologi : karakteristik hujan, menganalisis hujan rencana dan analisis debit rencana untuk dapat mengevaluasi saluran drainase.
1. Penentuan Hujan Wilayah

Terdapat 4 stasiun hujan yang berpengaruh terhadap kawasan DAS saluran Sekunder UNESA, dan didapatkan 2 stasiun hujan dengan menggunakan metode thiessen ${ }^{[1]}$, yakni stasiun hujan Hujan Kandangan dan Stasiun Hujan Kebon Agung. Cari nilai koefisien masing-masing stasiun hujan, kemudian cari nilai curah hujan rata-rata maksimum sebagai hasil distribusi hujan. Dapat dilihat pada Tabel 1 dan Gambar 3.

Tabel 1. Curah Hujan Rata-Rata Maksimum

\begin{tabular}{rcc}
\hline NO & TAHUN & TOTAL Rmax $(\mathbf{m m})$ \\
\hline $\mathbf{1}$ & 2000 & 98.03 \\
$\mathbf{2}$ & 2001 & 121.39 \\
$\mathbf{3}$ & 2002 & 192.56 \\
$\mathbf{4}$ & 2003 & 103.57 \\
$\mathbf{5}$ & 2004 & 69.80 \\
$\mathbf{6}$ & 2005 & 82.79 \\
$\mathbf{7}$ & 2006 & 117.56 \\
$\mathbf{8}$ & 2007 & 92.15 \\
$\mathbf{9}$ & 2008 & 107.56 \\
$\mathbf{1 0}$ & 2009 & 77.75 \\
$\mathbf{1 1}$ & 2010 & 124.76 \\
$\mathbf{1 2}$ & 2011 & 81.24 \\
$\mathbf{1 3}$ & 2012 & 83.87 \\
$\mathbf{1 4}$ & 2013 & 70.77 \\
$\mathbf{1 5}$ & 2014 & 78.89 \\
$\mathbf{1 6}$ & 2015 & 62.75 \\
\hline
\end{tabular}

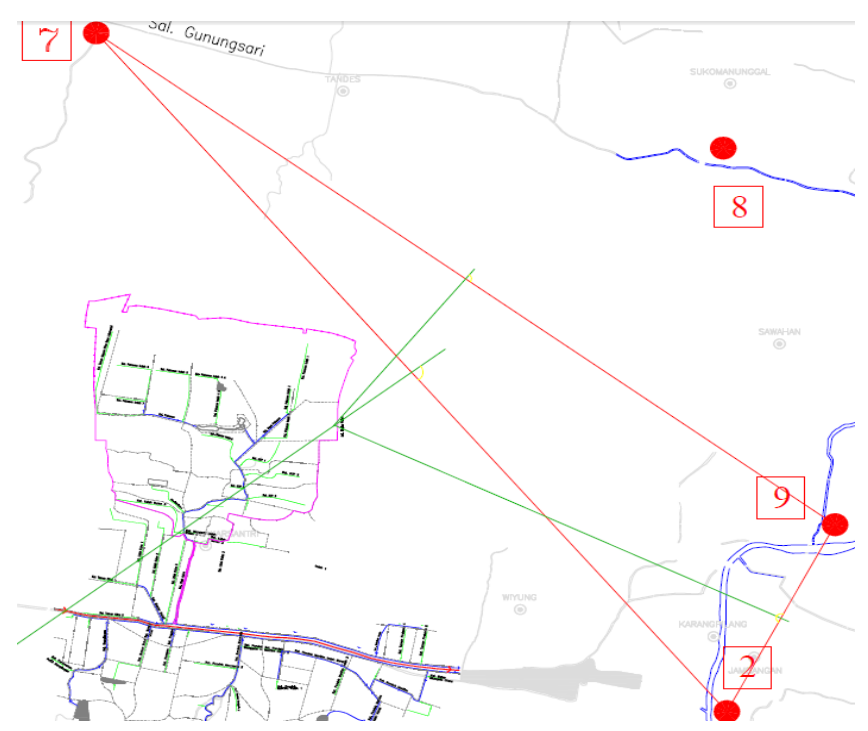

Gambar. 3.Polygon Thiessen Penentuan Luas Pengaruh Stasiun

\section{Perhitungan Parameter Statistik}

Analisis curah hujan maksimum harian rencana menggunakan metode Normal dan metode Gumbel yang dapat dilihat pada Tabel 2. 
JURNAL TEKNIK HIDROTEKNIK Vol. 2, No.1, (2017) ISSN : 2477-3212

Tabel 2.

Perhitungan Parameter Statistik Untuk Distribusi Normal dan Gumbel

\begin{tabular}{cccccc}
\hline TAHUN & $\begin{array}{c}\text { Rmax } \\
(\mathrm{mm})\end{array}$ & $(\mathrm{X}-\ddot{X})$ & $(\mathrm{X}-\ddot{X})^{2}$ & $(\mathrm{X}-\ddot{X})^{3}$ & $(\mathrm{X}-\ddot{X})^{4}$ \\
\hline $\mathbf{2 0 0 2}$ & 192.56 & 94.72 & 8972.41 & 849891.57 & 80504105 \\
\hline $\mathbf{2 0 1 0}$ & 124.76 & 26.92 & 724.77 & 19511.97 & 525292.92 \\
\hline $\mathbf{2 0 0 1}$ & 121.39 & 23.55 & 554.53 & 13058.30 & 307502.66 \\
\hline $\mathbf{2 0 0 6}$ & 117.56 & 19.72 & 388.99 & 7671.94 & 151312.18 \\
\hline $\mathbf{2 0 0 8}$ & 107.56 & 9.72 & 94.53 & 919.12 & 8936.44 \\
\hline $\mathbf{2 0 0 3}$ & 103.57 & 5.73 & 32.81 & 187.92 & 1076.34 \\
\hline $\mathbf{2 0 0 0}$ & 98.03 & 0.20 & 0.04 & 0.01 & 0.00 \\
\hline $\mathbf{2 0 0 7}$ & 92.15 & -5.69 & 32.38 & -184.25 & 1048.44 \\
\hline $\mathbf{2 0 1 2}$ & 83.87 & -13.97 & 195.27 & -2728.77 & 38131.91 \\
\hline $\mathbf{2 0 0 5}$ & 82.79 & -15.05 & 226.61 & -3411.20 & 51350.33 \\
\hline $\mathbf{2 0 1 1}$ & 81.24 & -16.60 & 275.59 & -4575.06 & 75950.13 \\
\hline $\mathbf{2 0 1 4}$ & 78.89 & -18.95 & 359.26 & -6809.36 & 129065.00 \\
\hline $\mathbf{2 0 0 9}$ & 77.75 & -20.09 & 403.54 & -8106.58 & 162848.42 \\
\hline $\mathbf{2 0 1 3}$ & 70.77 & -27.07 & 732.70 & -19833.1 & 536849.52 \\
\hline $\mathbf{2 0 0 4}$ & 69.80 & -28.04 & 786.43 & -22054.4 & 618479.86 \\
\hline $\mathbf{2 0 1 5}$ & 62.75 & -35.09 & 1231.20 & -43200.8 & 1515847.4 \\
\hline JUMLAH & 1565.4 & 0.00 & 15011.1 & 780337.4 & 84627796.6 \\
\hline
\end{tabular}

$$
\begin{aligned}
& \bar{X}=\frac{1}{16} x 1565.43=97.8397 \mathrm{~mm} \\
& S=\sqrt{\frac{1}{16-1} \times 15011.06}=31.6344 \mathrm{~mm} \\
& C_{v}=\frac{31.6344}{97.8397}=0.32333 \\
& C S=\frac{16}{(16-1) \times(16-2) \times 31.6344^{3}} \times 780337.44=1.878 \\
& C_{k}=\frac{16^{2}}{(16-1)(16-2)(16-3) 31.6344^{4}} \times 84627796.6=7.9241
\end{aligned}
$$

Perhitungan parameter statistik untuk distribusi LogPearson Tipe III dan Log Normal dapat dilihat pada Tabel 3. Tabel. 3.

Perhitungan Parameter Statistik Untuk Distribusi Log-Pearson Tipe III dan Log Normal

\begin{tabular}{cccccc}
\hline TAHUN & $\begin{array}{c}\mathbf{R}(\mathbf{X}) \\
(\mathbf{m m})\end{array}$ & $\begin{array}{c}\text { Y=LOG } \\
\mathbf{X}\end{array}$ & $(\mathbf{Y}-\overline{\mathbf{y}})$ & $(\mathbf{Y}-\overline{\mathbf{y}})^{\mathbf{2}}$ & $(\mathbf{Y}-\overline{\mathbf{y}})^{\mathbf{3}}$ \\
\hline $\mathbf{2 0 0 2}$ & 192.56 & 2.28 & 0.31 & 0.09707 & 0.03024 \\
$\mathbf{2 0 1 0}$ & 124.76 & 2.10 & 0.12 & 0.01515 & 0.00186 \\
\hline $\mathbf{2 0 0 1}$ & 121.39 & 2.08 & 0.11 & 0.01236 & 0.00137 \\
\hline $\mathbf{2 0 0 6}$ & 117.56 & 2.07 & 0.10 & 0.00946 & 0.00092 \\
\hline $\mathbf{2 0 0 8}$ & 107.56 & 2.03 & 0.06 & 0.00344 & 0.00020 \\
\hline $\mathbf{2 0 0 3}$ & 103.57 & 2.02 & 0.04 & 0.00178 & 0.00008 \\
\hline $\mathbf{2 0 0 0}$ & 98.03 & 1.99 & 0.02 & 0.00034 & 0.00001 \\
\hline $\mathbf{2 0 0 7}$ & 92.15 & 1.96 & -0.01 & 0.00007 & 0.00000 \\
\hline $\mathbf{2 0 1 2}$ & 83.87 & 1.92 & -0.05 & 0.00244 & -0.00012 \\
\hline $\mathbf{2 0 0 5}$ & 82.79 & 1.92 & -0.06 & 0.00303 & -0.00017 \\
\hline $\mathbf{2 0 1 1}$ & 81.24 & 1.91 & -0.06 & 0.00400 & -0.00025 \\
\hline $\mathbf{2 0 1 4}$ & 78.89 & 1.90 & -0.08 & 0.00578 & -0.00044 \\
\hline $\mathbf{2 0 0 9}$ & 77.75 & 1.89 & -0.08 & 0.00677 & -0.00056 \\
\hline $\mathbf{2 0 1 3}$ & 70.77 & 1.85 & -0.12 & 0.01517 & -0.00187 \\
\hline $\mathbf{2 0 0 4}$ & 69.80 & 1.84 & -0.13 & 0.01669 & -0.00216 \\
\hline $\mathbf{2 0 1 5}$ & 62.75 & 1.80 & -0.18 & 0.03076 & -0.00540 \\
\hline JUMLAH & 1565.43 & 31.57 & $-2 . E-15$ & 0.22431 & 0.02373 \\
\hline & & & & & \\
\hline
\end{tabular}

$$
\begin{aligned}
& \bar{Y}=\frac{1}{16} \times 31.57=1.97 \mathrm{~mm} \\
& S=\sqrt{\frac{1}{16-1} \times 0.22431}=0.122285 \mathrm{~mm} \\
& C_{v}=\frac{0.122285}{1.97}=0.061979 \\
& C S=\frac{16}{(16-1) \times(16-2) \times 0.122285^{3}} \times 0.02373=0.988617 \\
& C_{k}=\frac{16^{2}}{(16-1)(16-2)(16-3) 0.122285^{4}} \times 0.01147=4.81185
\end{aligned}
$$

Dari parameter-parameter diatas, dipilih jenis distribusi yang sesuai untuk digunakan dalam tugas akhir ini. Pemilihan jenis distribusi ${ }^{[2]}$ yang sesuai dapat dilihat pada Tabel 4.
Tabel. 4.

Pemilihan Jenis Distribusi yang Sesuai

\begin{tabular}{cccc}
\hline Distribusi & Syarat & Hasil & Kesimpulan \\
\hline Normal & $\mathrm{Cs}=0$ & 1.878 & $\mathrm{NO}$ \\
\cline { 2 - 4 } & $\mathrm{Ck}=3$ & 7.924 & $\mathrm{NO}$ \\
\hline \multirow{2}{*}{ Gumbel } & $\mathrm{Cs}=1.139$ & 1.878 & $\mathrm{NO}$ \\
\cline { 2 - 4 } & $\mathrm{Ck}=5.402$ & 7.924 & $\mathrm{NO}$ \\
\hline Log-Pearson & $\mathrm{Cs}=$ Fleksibel & 0.988 & $\mathrm{OK}$ \\
\cline { 2 - 4 } III & $\mathrm{Ck}=4.466$ & 4.812 & $\mathrm{OK}$ \\
\hline Log-Normal & $\mathrm{Cs}=0.186$ & 0.988 & $\mathrm{NO}$ \\
\cline { 2 - 4 } & $\mathrm{Ck}=3.062$ & 4.812 & $\mathrm{NO}$ \\
\hline
\end{tabular}

\begin{tabular}{|c|c|c|c|c|c|}
\hline NO. & $\begin{array}{c}\text { Nilai Batas Sub } \\
\text { Kelompok }\end{array}$ & $\mathbf{O i}$ & $\mathbf{E i}$ & (Oi-Ei) & $(\mathbf{O i}-\mathbf{E i})^{2} / \mathbf{E i}$ \\
\hline $\mathbf{1}$ & $X \leq 73.926$ & 3 & 3.2 & -0.2 & 0.0125 \\
\hline 2 & $73.926<X<82.423$ & 3 & 3.2 & -0.2 & 0.0125 \\
\hline 3 & $82.423<X<93.747$ & 3 & 3.2 & -0.2 & 0.0125 \\
\hline 4 & $\begin{array}{c}93.747<X< \\
116.374\end{array}$ & 3 & 3.2 & -0.2 & 0.0125 \\
\hline 5 & $X \geq 116.374$ & 4 & 3.2 & 0.8 & 0.2 \\
\hline & JUMLAH & 16 & 16 & 0 & 0.25 \\
\hline
\end{tabular}

Pada tabel 4, dapat dilihat bahwa distribusi Log Pearson III saja yang dapat digunakan. Kemudian dilakukan uji kecocokan yaitu uji Chi-Kuadrat dan uji SmirnovKolmogorov untuk menentukan distribusi tersebut cocok untuk digunakan ${ }^{[3]}$ atau tidak. Tabel 5 perhitungan Uji chi Square dan tabel 6 perhitungan uji Smirnov-Kolmogorov.

Tabel. 5.

Uji Chi-Kuadrat metode Log-Perason III

Chi-Kuadrat $0.25<5.991$ nilai Chi-Kritis $(\mathrm{OK})$ $(\mathbf{Y}-\overline{\mathbf{y}})^{4}$ Tabel. 6. 0.00942 Pemilihan Jenis Distribusi yang Sesuai

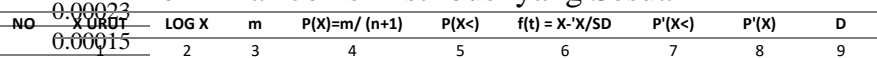
\begin{tabular}{llllllllll}
1 & 0.0969 .99 & 2.28 & 1 & 0.059 & 0.941 & 2.55 & 0.9946 & 0.0054 & 0.053 \\
\hline
\end{tabular} \begin{tabular}{llllllllll}
$\mathbf{2}$ & $0 .(2066) 6$ & 2.10 & 2 & 0.118 & 0.882 & 1.01 & 0.8438 & 0.1562 & 0.039 \\
\hline
\end{tabular} \begin{tabular}{llllllllll}
4 & $0.0(\mathrm{OO})(0)$ & 2.07 & 4 & 0.235 & 0.765 & 0.80 & 0.7881 & 0.2119 & 0.023 \\
\hline 5 & 2.03 & 5 & 0.294 & 0.706 & 0.48 & 0.6844 & 0.3156 & 0.021
\end{tabular} \begin{tabular}{llllllllll}
5 & $0 .(\mathrm{A}(\mathrm{B}) \bar{F} \mathrm{f})$ & 2.03 & 5 & 0.294 & 0.706 & 0.48 & 0.6844 & 0.3156 & 0.021 \\
\hline 6 & 0.02 & 2.02 & 6 & 0.353 & 0.647 & 0.35 & 0.6368 & 0.3632 & 0.010
\end{tabular}

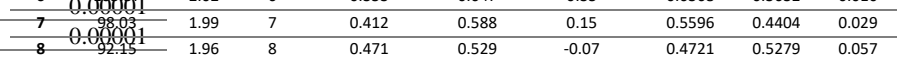
\begin{tabular}{llllllllll}
9 & 0.080 .992 & 1.92 & 9 & 0.529 & 0.471 & -0.40 & 0.3446 & 0.6554 & 0.126 \\
\hline
\end{tabular} \begin{tabular}{lllllllllll}
10 & 0.082993 & 1.92 & 10 & 0.588 & 0.412 & -0.45 & 0.3264 & 0.6736 & 0.085 \\
\hline 11 & 0.0810405 & 1.91 & 11 & 0.647 & 0.353 & -0.52 & 0.3015 & 0.6985 & 0.051 \\
\hline
\end{tabular} \begin{tabular}{llllllllll}
12 & 0.080 .0233 & 1.90 & 12 & 0.706 & 0.294 & -0.62 & 0.2676 & 0.7324 & 0.027 \\
\hline & 0.00088 & 1.89 & 13 & 0.765 & 0.235 & -0.67 & 0.2514 & 0.7486 & 0.016
\end{tabular} \begin{tabular}{lllllllllll}
13 & 0.070728 & 1.89 & 13 & 0.85 & 0.176 & -1.01 & 0.1562 & 0.8438 & 0.020 \\
\hline 14 & 0.009795 & 1.85 & 14 & 0.824 & 0.176 & -1.06 & 0.1446 & 0.8554 & 0.027
\end{tabular} \begin{tabular}{llllllllll}
15 & $0.0991^{84} 7$ & 1.84 & 15 & 0.882 & 0.118 & -1.06 & 0.1446 & 0.8554 & 0.027 \\
\hline 16 & 62.75 & 1.80 & 16 & 0.941 & 0.059 & -1.43 & 0.0764 & 0.9236 & 0.018 \\
\hline
\end{tabular}

$$
\mathrm{D}_{\mathrm{O}}=0.053<\mathrm{D}_{\max }=0.33(\mathrm{OK})
$$

Kesimpulan yang didapat pada tabel 5 dan tabel 6 bahwa distribusi Log Pearson III dapat digunakan dalam perhitungan hujan rencana dengan nilai hujan rencana 5 tahun sebesar:

$$
\begin{aligned}
\mathrm{K}_{\mathrm{T}} & =0.759252(\text { Interpolasi }) \\
\mathrm{Y}_{5} & =1.97+0.759252 \times 0.122285 \\
= & 2.0659 \mathrm{~mm}=\text { Antilog } \mathrm{X}_{5}=\underline{116.3741 \mathrm{~mm}}
\end{aligned}
$$




\section{Analisis Debit}

Setelah nilai hujan rencana didapatkan, tahap selanjutnya adalah melakukan analisis debit. Tujuan dari analisis debit untuk menghitung besarnya debit banjir rencana yang terjadi selama periode ulang yang ditentukan yang digunakan dalam evaluasi dan perencanaan kapasitas saluran. Dalam tugas akhir ini, perhitungan debit banjir menggunakan perhitungan manual.

Metode yang digunakan dalam perhitungan debit banjir saluran sekunder UNESA adalah Metode Rasional ${ }^{[4]}$. Dalam perhitungan metode ini diperlukan ilai Koefisien pengaliran (C), Intensitas Hujan (I), dan Luas daerah Pengaliran (A). Perhitungan dengan metode rasional hanya digunakan untuk saluran tersier yang memasuki saluran Sekunder UNESA, sedang untuk perhitungan Debit di Saluran UNESA menggunakan superposisi Hidrograf dari saluran tersier karena jenis aliran merupakan Unsteady Flow. Perhitungan debit saluran tersier dapat dilihat pada tabel 7 .

Tabel. 7.

Perhitungan Debit Metode Rasional

\begin{tabular}{cccccc}
\hline & & \multicolumn{4}{c}{ PERHITUNGAN DEBIT } \\
RENCANA 5 TAHUN \\
\cline { 3 - 6 } NO. & Saluran yang ditinjau & $\begin{array}{c}\mathrm{A} \\
(\mathrm{km} 2)\end{array}$ & $\mathrm{C}$ & $\begin{array}{c}\mathrm{I} \\
(\mathrm{mm} / \mathrm{jam})\end{array}$ & $\begin{array}{c}\mathrm{Q} \\
(\mathrm{m} 3 / \mathrm{s})\end{array}$ \\
\hline $\mathbf{1}$ & S7 S. Dari Pond Pakuwon & 2.02 & 0.48 & 60.99 & 16.6 \\
\hline $\mathbf{2}$ & T9 S. Pakuwon Indah 8 & 0.28 & 0.33 & 155.06 & 4.06 \\
\hline $\mathbf{3}$ & S8 S. Sekunder Citraland & 0.66 & 0.36 & 62.33 & 4.07 \\
\hline $\mathbf{4}$ & T10 S. IKIP 1 & 0.17 & 0.42 & 102.25 & 1.99 \\
\hline $\mathbf{5}$ & T11 S. IKIP 2 & 0.17 & 0.48 & 104.39 & 2.38 \\
\hline $\mathbf{6}$ & T12 S. IKIP 4 & 0.07 & 0.27 & 142.02 & 0.71 \\
\hline $\mathbf{7}$ & T13 S. IKIP 3 & 0.14 & 0.39 & 89.21 & 1.33 \\
\hline $\mathbf{8}$ & T14 S. IKIP 5 & 0.13 & 0.31 & 62.88 & 0.70 \\
\hline $\mathbf{9}$ & T15 S. IKIP 6 & 0.103 & 0.36 & 85.36 & 0.89 \\
\hline $\mathbf{1 0}$ & T16 S. Lidah Kulon 4 & 0.11 & 0.47 & 111.06 & 1.63 \\
\hline $\mathbf{1 1}$ & T17 S. Lidah Kulon 3 & 0.10 & 0.43 & 100.63 & 1.23 \\
\hline $\mathbf{1 2}$ & T18 S. Menganti L W 1 & 0.05 & 0.40 & 172.85 & 1.06 \\
\hline
\end{tabular}

Setelah menghitung dan mendapatkan Hidrograf satuan tiap inlet saluran UNESA, debit yang masuk di tiap saluran-saluran UNESA (gambar 4) dapat dicari dari superposisi hidrograf antar outlet saluran yang masuk. Gambar 5 merupakan contoh superposisi dari saluran S7 dan saluran S9 (outlet sekunder citraland dan saluran pakuwon indah 8) dengan waktu lama hujan 4 jam. Tabel 8 merupakan rekapitulasi nilai Debit saluran UNESA
Gambar 4.Skema Jaringan Saluran Sekunder UNESA

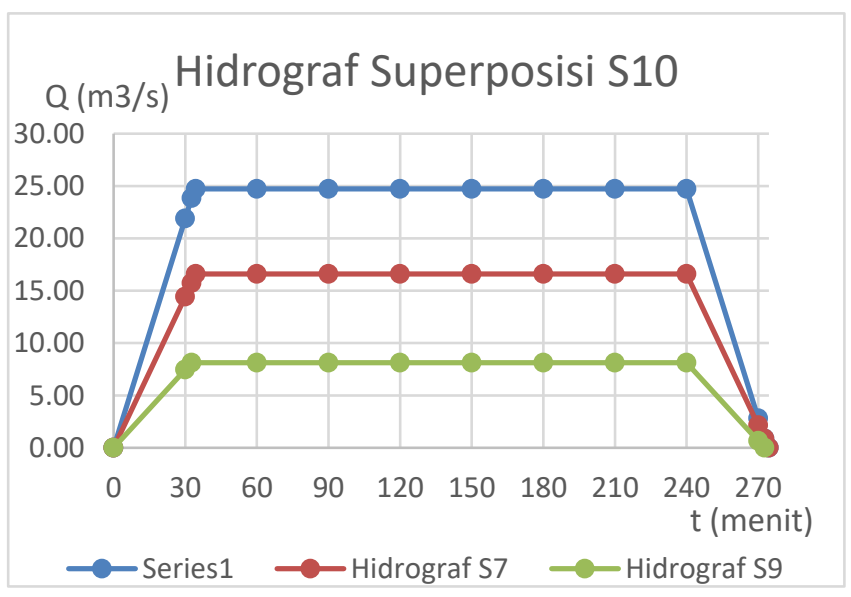

Gambar 5.Hidrograf Superposisi S10 (Sekunder UNESA)

Tabel. 8.

Perhitungan Debit Metode Rasional

\begin{tabular}{|c|c|c|c|c|}
\hline No & Saluran & $\begin{array}{c}\text { Potongan } \\
\text { penampang }\end{array}$ & $\mathbf{L}(\mathbf{m})$ & Q Hidrologi \\
\hline 1 & S10 & Potongan B & 23.3 & 24.73 \\
\hline 2 & S11 & Potongan $\mathrm{C}$ & 98.7 & 26.71 \\
\hline 3 & S12 & Potongan D & 112 & 29.10 \\
\hline 4 & S13 & Potongan D & 57.4 & 29.81 \\
\hline 5 & S14 & Potongan E & 38.6 & 31.15 \\
\hline 6 & \multirow{11}{*}{ S15 } & Potongan F & 46.2 & 31.84 \\
\hline 7 & & Potongan $\mathrm{G}$ & 46.1 & 31.84 \\
\hline 8 & & Potongan I & 56.1 & 31.84 \\
\hline 9 & & Potongan $\mathrm{H}$ & 40.1 & 31.84 \\
\hline 10 & & Potongan J & 45.6 & 31.84 \\
\hline 11 & & Potongan K & 47.4 & 31.84 \\
\hline 12 & & Potongan L & 30.7 & 31.84 \\
\hline 13 & & Potongan M & 43.8 & 31.84 \\
\hline 14 & & Potongan N & 34.2 & 31.84 \\
\hline 15 & & Potongan $\mathrm{O}$ & 67.7 & 31.84 \\
\hline 16 & & Potongan $\mathrm{P}$ & 22.2 & 31.84 \\
\hline 17 & \multirow{5}{*}{ S16 } & Potongan Q & 55.1 & 32.73 \\
\hline 18 & & Potongan $\mathrm{R}$ & 15.9 & 32.73 \\
\hline 19 & & Potongan S & 77.9 & 32.73 \\
\hline 20 & & Potongan $\mathrm{T}$ & 77.4 & 32.73 \\
\hline 21 & & Potongan U & 64.7 & 32.73 \\
\hline 22 & \multirow{3}{*}{ S17 } & Potongan V & 52.3 & 34.36 \\
\hline 23 & & Potongan X & 8.61 & 34.36 \\
\hline 24 & & Potongan Y & 143 & 34.36 \\
\hline
\end{tabular}

\section{B. Analisis Hidrolika}

Analisis Hidrolika ialah analisis kapasitas penampang saluran terhadap debit banjir yang terjadi. Dalam tugas akhir ini, analisis hidrolika diperlukan untuk mengevaluasi saluran eksisting UNESA. Data pada analisis ini menggunakan data sekunder saluran dengan dicocokkan terhadap kondisi di lapangan. 
1. Perhitungan Debit Hidrolika

Tabel 9 merupakan rekapitulasi perhitungan debit hidrolika

Tabel. 9.

Perhitungan Debit Saluran Eksisting UNESA

\begin{tabular}{|c|c|c|c|c|c|c|}
\hline $\begin{array}{c}\text { No } \\
\text { • }\end{array}$ & $\begin{array}{c}\text { Salura } \\
\mathbf{n}\end{array}$ & $\begin{array}{c}\text { Potongan } \\
\text { penampa } \\
\text { ng }\end{array}$ & $\begin{array}{c}\mathbf{L} \\
(\mathbf{m})\end{array}$ & $\begin{array}{c}\mathbf{n} \\
\text { (salura } \\
\mathbf{n})\end{array}$ & $\begin{array}{c}\mathbf{S} \\
\text { (salura } \\
\mathbf{n})\end{array}$ & $\begin{array}{c}\text { QHIDROLI } \\
\text { KA } \\
\text { (m3/det) }\end{array}$ \\
\hline 1 & $\mathrm{~S} 10$ & $\begin{array}{c}\text { Potongan } \\
\text { B }\end{array}$ & $\begin{array}{c}23 . \\
3\end{array}$ & 0.035 & 0.0052 & 14.75 \\
\hline 2 & S11 & $\begin{array}{c}\text { Potongan } \\
\text { C }\end{array}$ & $\begin{array}{c}98 . \\
7\end{array}$ & 0.035 & 0.00571 & 33.05 \\
\hline 3 & S12 & $\begin{array}{c}\text { Potongan } \\
\text { D }\end{array}$ & 112 & 0.0279 & 0.00571 & 12.79 \\
\hline 4 & S13 & $\begin{array}{c}\text { Potongan } \\
\text { D }\end{array}$ & $\begin{array}{c}57 . \\
4\end{array}$ & 0.0279 & 0.00571 & 12.79 \\
\hline 5 & S14 & $\begin{array}{c}\text { Potongan } \\
\text { E }\end{array}$ & $\begin{array}{c}38 . \\
6\end{array}$ & 0.02 & 0.00571 & 63.82 \\
\hline 6 & \multirow{11}{*}{$\mathrm{S} 15$} & $\begin{array}{c}\text { Potongan } \\
\text { F }\end{array}$ & $\begin{array}{c}46 . \\
2\end{array}$ & 0.035 & $\begin{array}{c}0.00367 \\
7\end{array}$ & 6.78 \\
\hline 7 & & $\begin{array}{c}\text { Potongan } \\
\text { G }\end{array}$ & $\begin{array}{c}46 . \\
1\end{array}$ & 0.035 & $\begin{array}{c}0.00325 \\
5\end{array}$ & 5.81 \\
\hline 8 & & $\begin{array}{c}\text { Potongan } \\
\text { I }\end{array}$ & $\begin{array}{c}56 . \\
1\end{array}$ & 0.035 & $\begin{array}{c}0.00267 \\
3\end{array}$ & 5.07 \\
\hline 9 & & $\begin{array}{c}\text { Potongan } \\
\mathrm{H}\end{array}$ & $\begin{array}{c}40 . \\
1\end{array}$ & 0.035 & $\begin{array}{c}0.00374 \\
1\end{array}$ & 4.40 \\
\hline 10 & & $\begin{array}{c}\text { Potongan } \\
\mathrm{J}\end{array}$ & $\begin{array}{c}45 . \\
6\end{array}$ & 0.035 & $\begin{array}{c}0.00328 \\
7\end{array}$ & 3.70 \\
\hline 11 & & $\begin{array}{c}\text { Potongan } \\
\mathrm{K}\end{array}$ & $\begin{array}{c}47 . \\
4\end{array}$ & 0.035 & $\begin{array}{c}0.00316 \\
7\end{array}$ & 15.13 \\
\hline 12 & & $\begin{array}{c}\text { Potongan } \\
\text { L }\end{array}$ & $\begin{array}{c}30 . \\
7\end{array}$ & 0.035 & $\begin{array}{c}0.01855 \\
5\end{array}$ & 1.98 \\
\hline 13 & & $\begin{array}{c}\text { Potongan } \\
\mathrm{M}\end{array}$ & $\begin{array}{c}43 . \\
8\end{array}$ & 0.035 & $\begin{array}{c}0.01300 \\
5\end{array}$ & 33.82 \\
\hline 14 & & $\begin{array}{c}\text { Potongan } \\
\mathrm{N}\end{array}$ & $\begin{array}{c}34 . \\
2\end{array}$ & 0.035 & $\begin{array}{c}0.01668 \\
1\end{array}$ & 19.32 \\
\hline 15 & & $\begin{array}{c}\text { Potongan } \\
\mathrm{O}\end{array}$ & $\begin{array}{c}67 . \\
7\end{array}$ & 0.035 & $\begin{array}{c}0.00841 \\
8\end{array}$ & 17.73 \\
\hline 16 & & $\begin{array}{c}\text { Potongan } \\
\text { P }\end{array}$ & $\begin{array}{c}22 . \\
2\end{array}$ & 0.035 & $\begin{array}{c}0.01489 \\
8\end{array}$ & 14.85 \\
\hline 17 & \multirow{5}{*}{ S16 } & $\begin{array}{c}\text { Potongan } \\
\text { Q }\end{array}$ & $\begin{array}{c}55 . \\
1\end{array}$ & 0.035 & $\begin{array}{c}0.00908 \\
5\end{array}$ & 19.85 \\
\hline 18 & & $\begin{array}{c}\text { Potongan } \\
\text { R }\end{array}$ & $\begin{array}{c}15 . \\
9\end{array}$ & 0.035 & $\begin{array}{c}0.00441 \\
1\end{array}$ & 13.87 \\
\hline 19 & & $\begin{array}{c}\text { Potongan } \\
\text { S }\end{array}$ & $\begin{array}{c}77 . \\
9\end{array}$ & 0.02 & $\begin{array}{c}0.00330 \\
6\end{array}$ & 16.73 \\
\hline 20 & & $\begin{array}{c}\text { Potongan } \\
\mathrm{T}\end{array}$ & $\begin{array}{c}77 . \\
4\end{array}$ & 0.02 & $\begin{array}{c}0.00090 \\
4\end{array}$ & 15.45 \\
\hline 21 & & $\begin{array}{c}\text { Potongan } \\
\mathrm{U}\end{array}$ & $\begin{array}{c}64 . \\
7\end{array}$ & 0.02 & $\begin{array}{c}0.00147 \\
7\end{array}$ & 14.30 \\
\hline 22 & \multirow{3}{*}{ S17 } & $\begin{array}{c}\text { Potongan } \\
\mathrm{V}\end{array}$ & $\begin{array}{c}52 . \\
3\end{array}$ & 0.02 & $\begin{array}{c}0.00179 \\
4\end{array}$ & 13.30 \\
\hline 23 & & $\begin{array}{c}\text { Potongan } \\
\text { X }\end{array}$ & $\begin{array}{c}8.6 \\
1\end{array}$ & 0.02 & $\begin{array}{c}0.00103 \\
4\end{array}$ & 20.64 \\
\hline 24 & & $\begin{array}{c}\text { Potongan } \\
\mathrm{Y}\end{array}$ & 143 & 0.035 & $\begin{array}{c}0.00258 \\
7\end{array}$ & 12.04 \\
\hline
\end{tabular}

\section{Evaluasi Saluran Sekunder UNESA}

Dari perhitungan di atas didapat nilai $Q$ hidrologi dan Q hidrolika eksisting saluran sekunder UNESA. Sehingga perhitungan evaluasi dapat dilakukan dengan membandingkan debit manakah yang lebih besar, apakah Q hidrolika eksisting atau Q hidrologi. Jika nilai Q hidrolika lebih besar dari nilai Q hidrologi maka penampang dapat menampung debit yang masuk. Sebaliknya apabila Q hidrologi yang lebih besar dari nilai Q hidrolika, maka penampang saluran eksisting tidak dapat menampung debit yang masuk dan dibutuhkan perencanaan saluran baru atau solusi lain untuk menampung debit di saluran sekunder UNESA. Hasil evaluasi dapat dilihat pada tabel 10.

Tabel. 10.

Perhitungan Evaluasi saluran Sekunder UNESA

\begin{tabular}{|c|c|c|c|c|c|}
\hline \multirow[b]{2}{*}{$\begin{array}{l}\mathbf{N} \\
\text { o. }\end{array}$} & \multirow[b]{2}{*}{$\begin{array}{l}\text { Salur } \\
\text { an }\end{array}$} & \multirow{2}{*}{$\begin{array}{c}\text { Potong } \\
\text { an } \\
\text { penampan } \\
\mathrm{g}\end{array}$} & \multicolumn{3}{|c|}{ Q (debit)(m3/det) } \\
\hline & & & $\begin{array}{l}\text { Hidroli } \\
\text { ka }\end{array}$ & $\begin{array}{l}\text { Hidrol } \\
\text { ogi }\end{array}$ & $\begin{array}{l}\text { delt } \\
\text { a }\end{array}$ \\
\hline 1 & S10 & $\begin{array}{l}\text { Potonga } \\
\text { n B }\end{array}$ & 14.75 & 24.73 & 9.97 \\
\hline 2 & S11 & $\begin{array}{l}\text { Potonga } \\
\mathrm{n} \mathrm{C}\end{array}$ & 33.05 & 26.71 & $\begin{array}{l}6.3 \\
4\end{array}$ \\
\hline 3 & $\mathrm{~S} 12$ & $\begin{array}{l}\text { Potonga } \\
\text { n D }\end{array}$ & 12.79 & 29.10 & $\begin{array}{r}- \\
16.31\end{array}$ \\
\hline 4 & $\mathrm{~S} 13$ & $\begin{array}{l}\text { Potonga } \\
\text { n D }\end{array}$ & 12.79 & 29.81 & $\begin{array}{r}- \\
17.02\end{array}$ \\
\hline 5 & S14 & $\begin{array}{l}\text { Potonga } \\
\mathrm{nE}\end{array}$ & 63.82 & 31.15 & $\begin{array}{c}32 . \\
67\end{array}$ \\
\hline 6 & \multirow{13}{*}{ S15 } & $\begin{array}{l}\text { Potonga } \\
\text { n F }\end{array}$ & 6.78 & 31.84 & $\begin{array}{r}- \\
25.07\end{array}$ \\
\hline 7 & & $\begin{array}{l}\text { Potonga } \\
\text { n G }\end{array}$ & 5.81 & 31.84 & 26.04 \\
\hline 8 & & $\begin{array}{l}\text { Potonga } \\
\text { n I }\end{array}$ & 5.07 & 31.84 & $\begin{array}{c}- \\
26.78\end{array}$ \\
\hline 9 & & $\begin{array}{l}\text { Potonga } \\
\mathrm{n} \mathrm{H}\end{array}$ & 4.40 & 31.84 & $27 . \overline{-}$ \\
\hline $0^{1}$ & & $\begin{array}{l}\text { Potonga } \\
\mathrm{n} \mathrm{J}\end{array}$ & 3.70 & 31.84 & $\begin{array}{r}- \\
28.15 \\
\end{array}$ \\
\hline & & Potong & \multicolumn{3}{|c|}{$Q$ (debit)(m3/det) } \\
\hline${ }^{\mathbf{N}}$ & & $\begin{array}{c}\text { an } \\
\text { penampan } \\
\mathrm{g}\end{array}$ & $\begin{array}{l}\text { Hidrol } \\
\text { ika }\end{array}$ & $\begin{array}{l}\text { Hidrol } \\
\text { ogi }\end{array}$ & $\underset{\text { ta }}{\text { del }}$ \\
\hline $1^{1}$ & & $\begin{array}{l}\text { Potonga } \\
\mathrm{n} \mathrm{K}\end{array}$ & 15.13 & 31.84 & $\begin{array}{r}- \\
16.71 \\
\end{array}$ \\
\hline $2^{1}$ & & $\begin{array}{l}\text { Potonga } \\
\mathrm{n} \mathrm{L}\end{array}$ & 1.98 & 31.84 & $\begin{array}{c}- \\
29.86\end{array}$ \\
\hline $3^{1}$ & & $\begin{array}{l}\text { Potonga } \\
\mathrm{n} \mathrm{M}\end{array}$ & 33.82 & 31.84 & $\begin{array}{l}1.9 \\
8\end{array}$ \\
\hline $4^{1}$ & & $\begin{array}{l}\text { Potonga } \\
\mathrm{n} \mathrm{N}\end{array}$ & 19.32 & 31.84 & $\begin{array}{c}- \\
12.52\end{array}$ \\
\hline $5^{1}$ & & $\begin{array}{l}\text { Potonga } \\
\mathrm{n} \mathrm{O}\end{array}$ & 17.73 & 31.84 & $\begin{array}{r}- \\
14.11\end{array}$ \\
\hline $6^{1}$ & & $\begin{array}{l}\text { Potonga } \\
\mathrm{n} \mathrm{P}\end{array}$ & 14.85 & 31.84 & $\begin{array}{r}- \\
17.00\end{array}$ \\
\hline $7^{1}$ & \multirow{5}{*}{ S16 } & $\begin{array}{l}\text { Potonga } \\
\mathrm{n} \mathrm{Q}\end{array}$ & 19.85 & 32.73 & $\begin{array}{r}- \\
12.88\end{array}$ \\
\hline $8^{1}$ & & $\begin{array}{l}\text { Potonga } \\
\mathrm{n} \mathrm{R}\end{array}$ & 13.87 & 32.73 & $\begin{array}{r}- \\
18.86\end{array}$ \\
\hline $9^{1}$ & & $\begin{array}{l}\text { Potonga } \\
\text { n S }\end{array}$ & 16.73 & 32.73 & $\begin{array}{r}- \\
16.00\end{array}$ \\
\hline $0^{2}$ & & $\begin{array}{l}\text { Potonga } \\
\mathrm{n} \mathrm{T}\end{array}$ & 15.45 & 32.73 & $\begin{array}{r}- \\
17.28\end{array}$ \\
\hline $1^{2}$ & & $\begin{array}{l}\text { Potonga } \\
\mathrm{n} \mathrm{U}\end{array}$ & 14.30 & 32.73 & $\begin{array}{r}- \\
18.42\end{array}$ \\
\hline $2^{2}$ & \multirow{3}{*}{ S17 } & $\begin{array}{l}\text { Potonga } \\
\mathrm{n} \mathrm{V}\end{array}$ & 13.30 & 34.36 & $\begin{array}{r}- \\
21.06\end{array}$ \\
\hline $3^{2}$ & & $\begin{array}{l}\text { Potonga } \\
\mathrm{n} \mathrm{X}\end{array}$ & 20.64 & 34.36 & $\begin{array}{r}- \\
13.72\end{array}$ \\
\hline $4^{2}$ & & $\begin{array}{l}\text { Potonga } \\
\text { n Y }\end{array}$ & 12.04 & 34.36 & $\begin{array}{r}- \\
22.32\end{array}$ \\
\hline
\end{tabular}

Dari tabel diatas dapat disimpulkan bahwa hampir seluruh penampang saluran sekunder UNESA tidak dapat menampung debit yang dikeluarkan oleh ketiga kawasan.

3. Analisis Hidrolika Tahap Perencanaan

Pada tahap perencanaan ini, saluran yang masuk ke saluran Sekunder UNESA dari ketiga kawasan ditahan/dikontrol sehingga debit yang mengalir 
tidak terlalu besar. Untuk kawasan Pakuwon Qizin= $7 \mathrm{~m}^{3} / \mathrm{det}$, kawasan Citraland $\mathrm{Q}_{\text {izin }}=3.5 \mathrm{~m}^{3} / \mathrm{det}$, dan kawasan UNESA Q izin $=4 \mathrm{~m}^{3} /$ det.

Pada tahap perencanaan sistem drainase UNESA, dapat dilihat pada skema gambar 6, adanya tambahan kolam tampung untuk menampung debit dari saluran sekunder UNESA sebesar $4 \mathrm{~m}^{3} /$ det. Jadi kawasan UNESA perlu untuk mengontrol debit yang masuk kedalam saluran Sekunder UNESA.

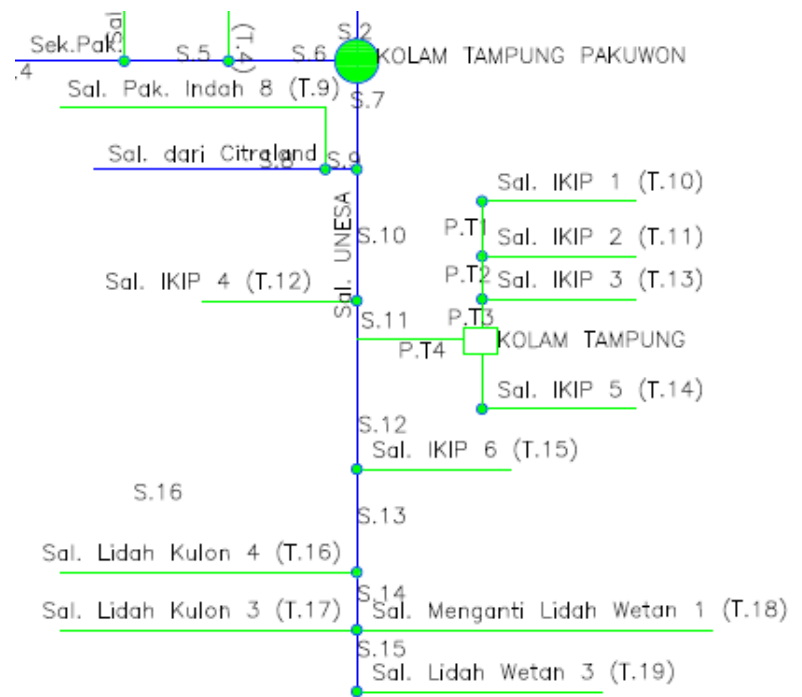

Gambar 6.Skema Drainase Sekunder UNESA Tahap Perencanaan

Pada tahap perencanaan ini, saluran tersier Unesa tidak langsung memasuki saluran Sekunder UNESA melainkan masuk kedalam saluran yang akan di tampung terlebih dahulu di kolam tampung lalu dikeluarkan ke Sekunder UNESA. Tabel 11 rekapitulasi perhitungan dimensi perencanaan saluran UNESA

Tabel. 11.

Rekapitulasi Dimensi Perencanaan Saluran

\begin{tabular}{ccccc}
\hline $\begin{array}{c}\text { SALURA } \\
\text { N }\end{array}$ & H $(\mathbf{m})$ & BENTUK & $\begin{array}{c}\text { B } \\
(\mathbf{m})\end{array}$ & $\begin{array}{c}\text { T } \\
(\mathbf{m})\end{array}$ \\
\hline P.T 1 & 1 & PERSEGI & 2 & 2 \\
\hline P.T 2 & 1.01 & PERSEGI & 3 & 3 \\
\hline P.T 3 & 1 & PERSEGI & 3.9 & 3.9 \\
\hline S10 & 1.36 & $\begin{array}{c}\text { TRAPESIU } \\
\text { M }\end{array}$ & 7 & 9.7 \\
\hline S11 & 1.34 & $\begin{array}{c}\text { TRAPESIU } \\
\text { M }\end{array}$ & 7 & 11.6 \\
\hline $\begin{array}{c}\text { SALURA } \\
\text { N }\end{array}$ & $\mathbf{H}(\mathbf{m})$ & BENTUK & $\mathbf{B}$ & $\mathbf{T}$ \\
\hline S12 & 1.22 & PERSEGI & 7.5 & 7.5 \\
\hline S13 & 1.24 & PERSEGI & 7.5 & 7.5 \\
\hline S14 & 1.24 & PERSEGI & 7.5 & 7.5 \\
\hline
\end{tabular}

4. Analisis Kolam Tampung, Pompa, dan Pintu Air

Perencanaan kolam tampung dilakukan sebagai salah satu solusi penyelesaian banjir yang terjadi pada saluran Sekunder UNESA yang belum dapat menampung debit banjir rencana. Luas kolam tampung yang direncanakan seluas $15800 \mathrm{~m}^{2}$ dengan kedalaman 1.8 meter + tinggi jagaan 0.2 meter. Perhitungan volume kolam tampung dapat dilihat pada tabel 12 .

Tabel. 12.

Perhitungan Volume Limpasan pada kondisi $t d=2 \mathrm{jam}$

\begin{tabular}{|c|c|c|c|c|c|}
\hline \multirow{2}{*}{$\begin{array}{c}\mathbf{t} \\
\text { (menit }\end{array}$} & \multicolumn{3}{|c|}{ Inflow } & \multicolumn{2}{|c|}{$\begin{array}{c}\text { Kolam } \\
\text { Tampung }\end{array}$} \\
\hline & $\begin{array}{c}Q \\
\text { inflow }\end{array}$ & $\begin{array}{c}V \text { inflow } \\
\left(\mathbf{m}^{3}\right)\end{array}$ & $\begin{array}{c}\mathrm{V} \\
\text { kumulatif }\end{array}$ & $\begin{array}{c}\mathrm{V} \\
\text { kolam }\end{array}$ & $\begin{array}{c}\mathbf{H} \\
\text { air }\end{array}$ \\
\hline O & 0 & 0 & 0 & 0 & 0 \\
\hline 10 & 2.86 & 858.5 & 858.5 & 858.5 & 0.05 \\
\hline 20 & 5.72 & 2575.5 & 3433.9 & 3433.9 & 0.22 \\
\hline 30 & 6.38 & 3632.1 & 7066.0 & 7066.0 & 0.45 \\
\hline 30.84 & 6.40 & 321.9 & 7388.0 & 7388.0 & 0.47 \\
\hline 40 & 6.40 & 3519.2 & 10907.1 & $\begin{array}{c}10907 . \\
1\end{array}$ & 0.69 \\
\hline 50 & 6.40 & 3841.6 & 14748.7 & $\begin{array}{c}14748 . \\
7\end{array}$ & 0.93 \\
\hline 60 & 6.40 & 3841.6 & 18590.3 & $\begin{array}{c}18590 . \\
3\end{array}$ & 1.18 \\
\hline 70 & 6.40 & 3841.6 & 22431.9 & $\begin{array}{c}22431 . \\
9\end{array}$ & 1.42 \\
\hline 80 & 6.40 & 3841.6 & 26273.5 & $\begin{array}{c}26273 . \\
5\end{array}$ & 1.66 \\
\hline 90 & 6.40 & 3841.6 & 30115.1 & $\begin{array}{c}30115 . \\
1\end{array}$ & 1.91 \\
\hline 100 & 6.40 & 3841.6 & 33956.8 & $\begin{array}{c}33956 . \\
8\end{array}$ & 2.15 \\
\hline 110 & 6.40 & 3841.6 & 37798.4 & $\begin{array}{c}37798 . \\
4\end{array}$ & 2.39 \\
\hline 120 & 6.40 & 3841.6 & 41640.0 & $\begin{array}{c}41640 . \\
0\end{array}$ & 2.64 \\
\hline 130 & 3.54 & 2983.1 & 44623.1 & $\begin{array}{c}44623 . \\
1\end{array}$ & 2.82 \\
\hline 140 & 0.68 & 1266.1 & 45889.2 & $\begin{array}{c}45889 . \\
2\end{array}$ & 2.90 \\
\hline 150 & 0.17 & 256.1 & 46145.3 & $\begin{array}{c}46145 . \\
3\end{array}$ & 2.92 \\
\hline 150.84 & 0.00 & 4.4 & 46149.7 & $\begin{array}{c}46149 . \\
7\end{array}$ & 2.92 \\
\hline
\end{tabular}

Dengan menggunakan kolam tampung diperlukan kedalaman kolam tampung sebesar 2.92 meter. Karena kolam tampung dinilai terlalu dalam, maka kolam tampung direncanakan kedalaman 2 meter dengan jagaan $0.2 \mathrm{~m}$. Maka volume yang bisa ditampung adalah $15800 \mathrm{~m}^{2} \mathrm{x}$ $1.8 \mathrm{~m}=28440 \mathrm{~m}^{3}$. Sehingga perlu adanya pengoperasian pompa pada menit ke-20 dengan kapasitas pompa $2.5 \mathrm{~m}^{3} / \mathrm{det}$. Gambar 7 memperlihatkan volume yang dikeluarkan oleh pompa hingga tinggi air di kolam mencapai 1.78 m. 
Gambar 7. Grafik Volume Tampungan dan Volume Pompa

Untuk mengeluarkan air dari kolam tampung maka direncanakan menggunakan pintu air. Pintu air akan dibuka apabila muka air di luar kawasan lebih rendah dari elevasi pintu air yaitu +8.285 .

$$
\begin{aligned}
& Q=\mu a b \sqrt{2 g h} \quad(1) \\
& \mathrm{Q}=\text { debit (digunakan debit yang }
\end{aligned}
$$
diizinkan dari kolam)

$$
\begin{aligned}
& \mu=\text { koefisien debit }(0.8) \\
& \mathrm{a}=\operatorname{tinggi} \text { bukaan pintu }(\mathrm{m}) \\
& \mathrm{b}=\text { lebar pintu }(\mathrm{m}) \\
& \mathrm{g}=\text { percepatan gravitasi }\left(9.8 \mathrm{~m} / \mathrm{det}^{2}\right) \\
& \mathrm{h}=\text { Beda tinggi muka air }(\mathrm{m})
\end{aligned}
$$

Tinggi bukaan pintu ${ }^{[5]}$ yang dibuka saat tinggi air di pembuang $=+8.285$ adalah sebesar 0.37 meter atau sama dengan $37 \mathrm{~cm}$

\section{Profil Muka Air Hilir Saluran UNESA}

Perhitungan profil muka air diperlukan untuk mengetahui apakah terjadi backwater di hilir saluran Sekunder UNESA atau tidak. Hal tersebut dapat diketahui dari perbedaan elevasi muka air antara hulu saluran Lidah Kulon dengan hilir saluran Sekunder UNESA. Dari hasil perhitungan perencanaan dimensi saluran Sekunder UNESA, didapat elevasi Muka Air hilir nya +8.092 dan elevasi dasar salurannya +6.852 . Dan dari hasil survey saluran Lidah Kulon didapat elevasi dasar saluran +5.45 dengan elevasi muka air +7.3 . Beda elevasi Muka Air antara hilir saluran Sekunder UNESA dan saluran Lidah Kulon sebesar +8.092$+7.3=0.792$ meter. Jadi tidak ada backwater pada perencanaan dimensi saluran Sekunder UNESA. Penampang Long Section dapat dilihat pada gambar 8.

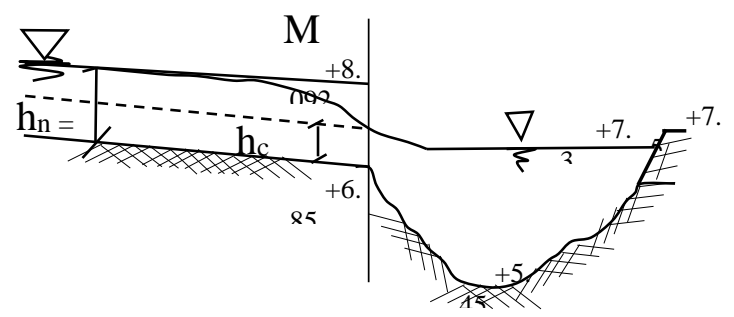

Gambar 8. Profil Muka Air di Hilir Saluran Sekunder UNESA

\section{KESIMPULAN}

1) Berdasarkan hasil survey dan data, kondisi eksisting saluran Sekunder UNESA tidak sesuai dengan saluran pembuang untuk kapasitas yang besar. Karena adanya penyempitan dan pelebaran yang tidak stabil pada saluran tersebut. Berdasarkan analisis debit banjir rencana 5 tahun, debit yang masuk

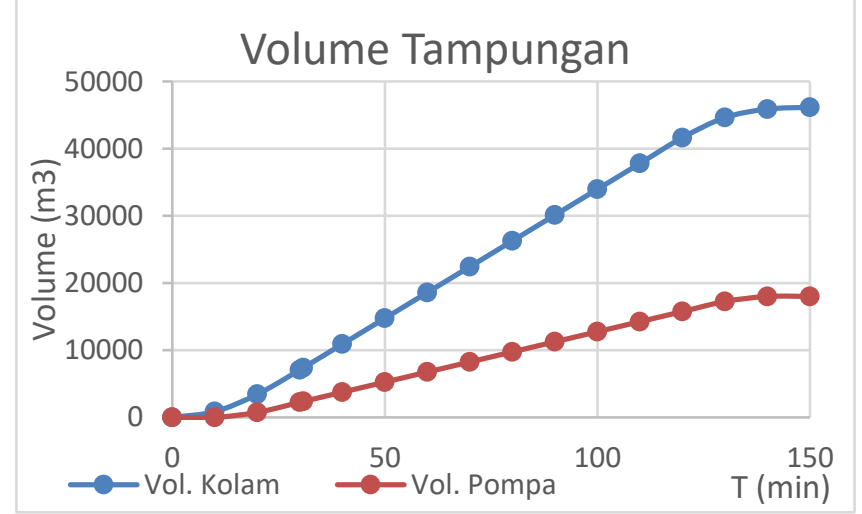

dari kawasan Pakuwon sebesar $16.6 \mathrm{~m}^{3} / \mathrm{det}$, dari kawasan Citraland sebesar $8.13 \mathrm{~m}^{3} / \mathrm{det}$, dan dari kawasan UNESA sebesar $8 \mathrm{~m}^{3} /$ det. Hal tersebut sangat membebani saluran Sekunder UNESA dengan jumlah debit yang masuk sebesar $34.36 \mathrm{~m}^{3} /$ det.

2) Hal yang menyebabkan terjadinya genangan pada saluran Sekunder UNESA karena debit limpasan yang masuk lebih besar dari kapasitas saluran. Debit limpasan di saluran $24.73 \mathrm{~m}^{3} /$ det sedangkan kapasitas saluran di hulu UNESA sebesar $14.75 \mathrm{~m}^{3} /$ det. Sehingga terjadi luapan air ke bagian jalan.

3) Dari hasil perencanaan Saluran Sekunder UNESA, debit yang mengalir dari tiap kawasan harus di kontrol terlebih dahulu sebelum dialirkan ke saluran Sekunder UNESA. Debit yang diperbolehkan untuk keluar dari kawasan Citraland sebesar 3.5 $\mathrm{m}^{3} /$ det, dari kawasan Pakuwon sebesar 7 $\mathrm{m}^{3} /$ det, dan dari kawasan UNESA sebesar 4 $\mathrm{m}^{3} /$ det. Kapasitas saluran Sekunder UNESA setelah adanya pengontrolan debit tiap kawasan menjadi $13.93 \mathrm{~m}^{3} /$ det.

4) Kontrol debit pada kawasan UNESA menggunakan fasilitas drainase Kolam tampung, pompa, dan pintu air. Hasil analisis Kolam tampung didapatkan luas sebesar $15800 \mathrm{~m}^{2}$ dengan kedalaman rencana 1.8 meter. Untuk pompa dibutuhkan 2 pompa dengan kapasitas $1.5 \mathrm{~m}^{3} /$ det dan 1 pompa dengan kapasitas $1 \mathrm{~m}^{3} /$ det.

\section{DAFTAR PUSTAKA}

[1] Triatmodjo, Bambang. 2014. Hidrologi Terapan. Yogyakarta: Beta Offset.

[2] BR, Sri Harto. 1993. Analisis Hidrologi. Jakarta : Gramedia Pustaka Utama.

[3] Suripin. 2004. Sistem Drainase Perkotaan yang Berkelanjutan. Yogyakarta: ANDI OFFSET 
JURNAL TEKNIK HIDROTEKNIK Vol. 2, No.1, (2017) ISSN : 2477-3212

[4] Sofia, fifi. 2006. Modul Drainase. Surabaya

[5] Soeanto, Soekibat Roedy. 2010. Modul Sistim dan Bangunan Irigasi. Surabaya 